\title{
CHEMICAL CHARACTER OF GROUND WATERS OF THE NORTHERN GREAT PLAINS
}

\author{
By H. B. RIFIENBURG
}

\section{INTRODUCTION}

The area discussed in this report forms the northern part of the Great Plains and extends from the eastern border of the Dakotas to the foothills of the Rocky Mountains and from the Canadian border into northern Wyoming and South Dakota. The section on geology is based on a number of published and unpublished reports on different parts of the area, and only enough description of each group or formation is given to show the relation of the ground water to the rock materials with which it comes into contact. The waters are discussed with reference to their chemical character and the alterations noted in the analyses of waters from different formations, of waters from the same formation in different localities, and of waters from different horizons in a formation.

Chemical and geologic results in published reports of numerous investigations of ground water in parts of Montana and the Dakotas, together with a large number of unpublished analyses made for individual reports, furnished the basis for a general study of the relation between the waters and the rocks of the northern Great Plains. About 400 of the unpublished analyses, made by Margaret D. Foster, C. S. Howard, and the writer, represent samples collected from the area by geologists of the United States Geological Survey and the North Dakota Geological Survey, and about 700 partial analyses were made in other laboratories for purposes that do not require analyses so complete as those made in the water-resources laboratory of the United States Geological Survey.

\section{GEOLOGY}

A review of the published reports on the geology of the northern Great Plains shows that the rocks above the granite are regarded as being almost entirely of sedimentary origin. These rocks range in 
thickness from about 1,000 feet $^{1}$ in the eastern part of the area to over 8,500 feet ${ }^{2}$ in the western part. The sedimentary rocks consist of shale and sandstone ${ }^{3}$ ranging in age from Paleozoic to Quaternary. ${ }^{4}$ The present paper relates to the quality of water from the Quaternary, Tertiary, and Cretaceous formations, which are shown in the accompanying comparison of stratigraphic sections. The Fort Union and Lance formations are fresh-water deposits, except that in North and South Dakota the Cannonball member of the Lance is marine. Bowen ${ }^{5}$ points out that the fossils indicate that the upper part of the Montana group changes from a fresh-water deposit in the western part of the area to a marine formation in the eastern part. All the formations below this are believed to be marine deposits.

In addition to the publications cited above, which deal with specific localities, a geologic report correlating the formations of the area ${ }^{6}$ has been published, and four reports on areas in Montana and one on North Dakota are in preparation.

1 Barry, J. G., and Melsted, V. J., The geology of northeastern North Dakota : North Dakota Geol. Survey Fifth Bienn. Rept., p. 149; 1908.

2 Thom, W. T., jr., Oil and gas prospects in and near the Crow Indian Reservation, Mont. : U. S. Geol., Survey Bull. 736, p. 36, 1922.

s Stone, R. W., and Calvert, W. R., Stratigraphic relations of the Livingston formation of Montana : Econ. Geology, vol. 5, p. 752, 1910. Clapp, C. H., Bevan, Arthur, and Lambert, G. S., Geology and gas prospects of central and eastern. Montana: Montana Univ. Bull. 4, 1921. Calvert, W. R., and others, Geology of the Standing Rock and Cheyenne River Indian reservations, North and South Dakota: U. S. Geol. Survey Bull. 575, 1914. U. S. Geol. Survey Geol. Atlas, Folios 117, 127, 156, 168, 181, and 209.

4 Leonard, A. G., North Dakota Geol. Survey 'Third Bienn. Rept., 1904. Todd, J. E., and Hall, C. M., Geology and water resources of part of the lower James River valley, S. Dak. : U. S. Geol. Survey Water-Supply Paper 90, 1904.

5 Bowen, C. F., Gradations from continental to marine conditions of deposition in central Montana during the Eagle and Judith River epochs: U. S. Geol. Survey Prof. Paper 125 , p. 11,1920 .

6 Thom, W. T., jr., and Dobbin, C. E., Stratigraphy of the Cretaceous-Eocene transition beds in eastern Montana and the Dakotas: Geol. Soc. America Bull., vol. 35, pp. 481-505, 1924. 
Comparison of stratigraphic divisions of Cenozoic and Mesozoic rocks in parts of Montana and the Dakotas

\begin{tabular}{|c|c|c|c|c|c|c|}
\hline System & Series & Group & $\begin{array}{c}\text { Eastern North } \\
\text { Dakota }\end{array}$ & $\begin{array}{l}\text { Northwestern } \\
\text { South Dakota }\end{array}$ & $\begin{array}{c}\text { Montana east } \\
\text { of 106th } \\
\text { meridian }\end{array}$ & $\begin{array}{l}\text { Northern } \\
\text { and central } \\
\text { Montana }\end{array}$ \\
\hline Quaternary. & & & Quaternary. & Quaternary. & Quaternary. & Quaternary. \\
\hline \multirow{3}{*}{ Tertiary. } & Miocene (?). & & & $\begin{array}{c}\text { Arikaree (?) } \\
\text { sandstone. }\end{array}$ & $\underset{\text { Arikaree (?) }}{\text { sandstone. }}$ & \\
\hline & Oligocene. & & & $\begin{array}{l}\text { White River } \\
\text { formation. }\end{array}$ & $\begin{array}{l}\text { White River } \\
\text { formation.a }\end{array}$ & \\
\hline & Eocene. & & . & $\begin{array}{l}\text { Fort Union } \\
\text { formation. }\end{array}$ & $\begin{array}{c}\text { Fort Union } \\
\text { formation } \\
\text { (Lebo andes- } \\
\text { itic mem- } \\
\text { ber at base). }\end{array}$ & $\begin{array}{l}\text { Fort Un ion } \\
\text { formation } \\
\text { (Lebo shale } \\
\text { member at } \\
\text { base). }\end{array}$ \\
\hline Tertiary (?). & Eocene (?). & & & $\begin{array}{l}\text { Lance forma- } \\
\text { tion. }\end{array}$ & $\begin{array}{l}\text { Lance forma- } \\
\text { tion. }\end{array}$ & $\begin{array}{l}\text { Lance forma- } \\
\text { tion. }\end{array}$ \\
\hline \multirow{8}{*}{ Cretaceous. } & \multirow{5}{*}{$\begin{array}{l}\text { Upper Cre- } \\
\text { taceous. }\end{array}$} & & & $\begin{array}{c}\text { F ox } \mathrm{Hills} \\
\text { sandstone. }\end{array}$ & $\begin{array}{c}\text { F ox } \mathrm{H} \text { il l l s } \\
\text { sandstone. }\end{array}$ & $\begin{array}{l}\text { Lennep sand- } \\
\text { stone. } b\end{array}$ \\
\hline & & Montana. & Pierre shale. & Pierre shale. & Pierre shale. & $\begin{array}{l}\text { Bearpaw shale. } \\
\text { Judith River } \\
\text { formation. } \\
\text { Claggett for- } \\
\text { mation. } \\
\text { Eagle sand- } \\
\text { stone. }\end{array}$ \\
\hline & & & $\begin{array}{l}\mathrm{Ni} \text { i b r a r a } \\
\text { shale. }\end{array}$ & $\begin{array}{l}\text { Niobrara for- } \\
\text { mation. }\end{array}$ & $\begin{array}{l}\mathrm{N} \text { i o b r a r a } \\
\text { shale. }\end{array}$ & \\
\hline & & Colorado. & Benton shale. & $\begin{array}{l}\text { Carlile shale. } \\
\text { Greenhorn } \\
\text { limestone. } \\
\text { Graner os } \\
\text { shale. }\end{array}$ & Benton shale. & Coloradoshale. \\
\hline & & & $\begin{array}{l}\text { Dakota sand- } \\
\text { stone. }\end{array}$ & $\begin{array}{l}\text { Dakota sand- } \\
\text { stone. }\end{array}$ & $\begin{array}{l}\text { Dakota sand- } \\
\text { stone. }\end{array}$ & (?) \\
\hline & \multirow{3}{*}{$\begin{array}{l}\text { Lower Cre- } \\
\text { taceous. }\end{array}$} & & & $\begin{array}{l}\text { Fuson forma- } \\
\text { tion. }\end{array}$ & $\begin{array}{l}\text { Fuson forma- } \\
\text { tion.c }\end{array}$ & \multirow{3}{*}{$\begin{array}{c}\text { Kootenai for- } \\
\text { mation. }\end{array}$} \\
\hline & & & & $\begin{array}{c}\text { Minnewaste } \\
\text { limestone. }\end{array}$ & (?) & \\
\hline & & & & $\begin{array}{l}\text { Lakota sand- } \\
\text { stone. }\end{array}$ & $\begin{array}{l}\text { Lakota sand- } \\
\text { stone.c }\end{array}$ & \\
\hline $\begin{array}{l}\text { Cretaceous } \\
\text { (?). }\end{array}$ & $\begin{array}{l}\text { Lower Cre- } \\
\text { taceous } \\
\text { (?). }\end{array}$ & & & $\begin{array}{l}\text { Morrison for- } \\
\text { mation. }\end{array}$ & $\begin{array}{l}\text { Morrison for- } \\
\text { mation. }\end{array}$ & $\begin{array}{l}\text { Morrison for- } \\
\text { mation. }\end{array}$ \\
\hline \multirow{2}{*}{ Jurassic. } & Upper Ju- & & & $\begin{array}{c}\mathrm{U} \text { n k p a p a } \\
\text { sandstone. }\end{array}$ & (?) & \multirow{2}{*}{$\begin{array}{l}\text { Ellis form a- } \\
\text { tion. }\end{array}$} \\
\hline & & & & $\begin{array}{l}\text { Sundance for- } \\
\text { mation. }\end{array}$ & $\begin{array}{l}\text { Sundance for- } \\
\text { mation. }\end{array}$ & \\
\hline
\end{tabular}

a Known only in extreme eastern part of State.

$c$ In Crazy Mountain region and probably represented in Bearpaw shale of some other areas.

$b$ Southeastern part of State, near Black Hills. 


\section{PRECIPITATION}

The precipitation in the northern Great Plains ranges from 10 to 30 inches a year, of which as much as 90 or 95 per cent may find its way into the ground. The portion that does not enter the ground may evaporate or run off. Only a small proportion of the precipitation is disposed of by run-off except where the slope is steep. The chief factors that regulate the absorption of water by the ground are surface slope, rate and seasonal distribution of precipitation, temperature of the air, texture of the soil, and vegetative cover. The soils of this area, except those overlying beds of shale, are relatively porous and readily absorb moisture. If, however, the rate of fall is very rapid, as it often is in the summer, or if the precipitation falls on saturated or frozen ground a large part of the water drains off before it can be absorbed.

\section{COMPOSITION OF RAIN WATER}

A study of about 200 articles on the composition of rain water in different parts of the world was made by the writer in 1923 and furnishes a basis for an estimate of the general composition of rain water. The following articles contain bibliographies, comprehensive summaries of results, or data of special significance:

Воотн, W. M., Water problems: Jour. Ind. and Eng. Chemistry, vol. 2, p. $503,1910$.

Crowther, Charles, and Stewart, D. W., Distribution of atmospheric impurities in the neighborhood of an industrial city: Jour. Agr. Sci., vol. 5, pp. 390-408, 1912.

Dote, R. B., Chlorine content of rain water at Tortugas, Fla.: Washington Acad. Sci. Jour., vol. 4, pp. 3-4, 1914.

MacIntiRe, W. H., and Young, J. B., Sulphur, calcium, magnesium, and potassium content and reaction of rain water at different points in Tennessee: Soil Sci., vol. 15, p. 205, 1923. Give results of analyses of rain water collected at different points in Tennessee and a short bibliography.

MrLLER, N. H. J., The amounts of nitrogen as ammonia and as nitric acid and of chlorine in the rain water collected at Rothamsted: Jour. Agr. Sci., vol. 1, pp. 280-303, 1905. Give tables of analyses of rain water collected at Rothamsted and reviews the literature up to 1905.

Russert, E. J., and RICHARDS, E. H., The amount and composition of rainfall at Rothamsted: Jour. Agr. Sci., vol. 9, pp. 309-337, 1919. Summarize analyses covering a period of 28 years, and give a list of references.

WILson, B. D., Sulphur supplied to the soil in rain water: Am. Soc. Agron. Jour., vol. 13, pp. 226-229, 1921.

A comparison of the published analyses shows the following average amounts of impurities in rain water, in parts per million: Chloride $(\mathrm{Cl}), 3.0$; nitrogen as $\mathrm{NO}_{3}, 0.2$; nitrogen as $\mathrm{NH}_{3}, 0.4$; sulphate $\left(\mathrm{SO}_{4}\right)$, 5.0. The amount of impurities occurring in rain water varies greatly with conditions and location. The smoke from cities and 
industrial centers may increase the sulphur and carbon dioxide content several hundred per cent over the amounts found in country districts. The quantities of chloride and of nitrogen do not vary widely. The hydrogen ion concentration $(\mathrm{pH})$ was not given in any of the papers cited.

In connection with the study several samples of rain water collected in Washington, D. C., were analyzed. The maximum and. minimum amounts of certain constituents in these waters are shown in the following table. The results are typical of the published analyses of rain waters collected in other cities. These waters probably contain a greater quantity of mineral constituents than rain which has fallen in the open country, as over the Great Plains.

TABLE 1.-Range in certain constituents of 23 samples of rain water collected at Washington, D. C., 1923-1924, in parts per million

\begin{tabular}{l|r|r|r}
\hline & $\begin{array}{r}\text { Sulphate } \\
\text { radicle } \\
\left(\mathrm{SO}_{4}\right)\end{array}$ & $\begin{array}{r}\text { Chloride } \\
\text { radicle } \\
(\mathrm{Cl})\end{array}$ & $\mathrm{pH}$ \\
\hline Maximum & $\begin{array}{r}17.0 \\
1.0\end{array}$ & $\begin{array}{r}\mathbf{3 . 0} \\
\text { Trace. }\end{array}$ & $\begin{array}{r}\mathbf{7 . 7} \\
4.4\end{array}$ \\
\hline
\end{tabular}

None of the samples contained the carbonate radicle $\left(\mathrm{CO}_{3}\right)$ or bicarbonate radicle $\left(\mathrm{HCO}_{3}\right)$.

\section{GENERAL CHARACTER OF GROUND WATER}

Ground waters are chiefly solutions of bicarbonates, sulphates, and chlorides of the alkaline earths and the alkalies. The amounts of these constituents that a water may contain depend on several factors, such as the origin of the water, the time it has been in contact with the rocks, the nature of the rocks, and the degree of concentration, if any, of the water.

Connate waters contain substances which they held in solution at the time of deposition of the beds that contain them, but the constituents of waters of meteoric origin are dissolved from the rock materials through which the waters pass. Meteoric waters entering the soil and rocks first take up soluble constituents from the soil, which always contains a quantity of decaying organic matter, humus, and some disintegrated rock particles. The water, after taking carbon dioxide from the air and from the organic matter and humus, acts vigorously on the rock particles-especially in areas like that here considered, where the amount of feldspar in the rocks is as much as 60 per cent-breaking them up and forming new compounds consisting of calcium, magnesium, and sodium bicarbonate, soluble silicates, free silicic acid, and hydrated aluminum silicate, an end product insoluble in water. ${ }^{7}$ In this area, where there is only a moderate

7 Buckman, H. O., The chemical and physical processes involved in the formation of residual clay: Am. Ceramic Soc, Trans., vol. 8, p. 336, 1911. 
amount of precipitation, the products of decomposition of the rocks remain in the soil or are transported to low places, where great quantities of dissolved matter are deposited by evaporation of the water. This concentration furnishes the soluble constituents for the alkali waters, which may continue to seep downward, carrying the mineral matter with them. Headden, ${ }^{8}$ Harris, ${ }^{9}$ and others have found that the occurrence of alkali in the soils of the Great Plains is practically universal. As the soil becomes saturated the water with its dissolved matter seeps downward, but that remaining within several feet of the surface is brought back by capillary action when the surface becomes dry, and the salts are deposited as the water evaporates. The constituents generally found in the soils or in low places where the water has evaporated are sulphates of sodium, calcium, and magnesium with smaller amounts of bicarbonate. Almost everywhere in this area the shale contains sulphides as pyrites, which upon exposure to the air are oxidized to iron oxides and sulphuric acid. The sulphuric acid then unites with calcium, with sodium, and with magnesium to form sulphates and replace part of the bicarbonate of the waters. Where large quantities of soluble compounds of calcium and magnesium are formed from rocky decay the shallow waters are hard.

\section{CHANGES IN GROUND WATER}

The chemical and physical reactions that take place in a water as it percolates through the rocks mar vary greatly. Ground waters of meteoric origin in this area may be altered through concentration by evaporation, base exchange, or adsorption of constituents without exchange, reduction of sulphate by carbonaceous solids or gases, concentration by evaporation with natural gas, or change in composition resulting from mixing with connate waters.

\section{BASE EXCHANGE}

It has been known since 1850 that clay, soil, and sandstone enter into chemical exchange with solutions, giving off some constituents and taking on others. The literature on base exchange has been reviewed by Sullivan ${ }^{10}$ and more recently by Renick, ${ }^{11}$ and the reactions were considered by Mills and Wells. ${ }^{12}$ Instances of base

${ }^{8}$ Headden, W. P., Alkalies in Colorado: Colorado Agr. Exper. Sta. Bull. 239, 1918.

- Harris, F. S., Soil alkali, its origin, nature, and treatment, New York, John Wiley \& Sons, 1919.

${ }^{10}$ Sullivan, E. C., The interaction between minerals and water solutions, with special reference to geologic phenomena : U. S. Geol. Survey Bull. 312, 1907.

Henick, B. C., Base exchange in ground water by silicates as illustrated in Montana : U. S. Geol. Survey Water-Supply Paper 520, pp. 53-72, 1924.

${ }_{12}$ Mills, R. V. A., and Wells, R. C., The evaporation and concentration of waters associated with petroleum and natural gas: U. S. Geol. Survey Bull. 693, p. 75, 1919. 
exchange in ground waters are noted in unpublished reports on waters in the Coastal Plain of Virginia (by H. B. Riffenburg, 1920), Mississippi (by C. S. Howard, 1921), and North Dakota (by H. B. Riffenburg, 1922). The commonly noted result of base exchange in ground water is softening by contact with rock materials that give up sodium in exchange for calcium and magnesium. The reverse reaction may take place, as pointed out by Mills and Wells, when strong solutions of sodium chloride come into contact with minerals that have previously abstracted calcium and magnesium from hard waters.

\section{ADSORPTION OF BASE AND ACID}

The amounts of the different acid ions that are adsorbed by clay, soil, and. other rock materials can not be determined without considerable investigation; but apparently the least soluble compounds are lost from solution first and are followed by other compounds in the reverse order of their solubility, because the weak acids have the greater tendency to form insoluble compounds whose salts are hydrolyzed by water. A water that has been in contact with the soil and contains calcium carbonate or sodium and potassium carbonate is alkaline in reaction. A solution containing a salt made up of a strong base and a weak acid (such as the carbonates, silicates, and phosphates of the alkalies and alkaline earths) is hydrolyzed, with the resulting formation of free alkali, which is adsorbed directly without substitution, forming insoluble silicates or aluminum silicates. Where such a reaction takes place the acid radicle may increase in concentration or be adsorbed by the colloid.

Way ${ }^{13}$ noted the fact that the weak acids are removed from solution by soils together with the bases.

Henneberg and Stohmann ${ }^{14}$ described experiments confirming Way's results. They found that in nitrate, chloride, and sulphate the acid radicle showed little change in concentration but that the acid radicle was precipitated as well as the base from solutions of carbonates, phosphates, or silicates.

Liebig ${ }^{15}$ showed that the acid radicle of sodium and potassium silicates was removed in part by soils. According to Kullenberg, ${ }^{16}$ the phosphate radicle is taken up by soils from solution in greater

\footnotetext{
1850.

${ }^{13}$ Way, J. T., The power of soils to absorb manure : Roy. Agr. Soc. Jour., vol. 11, p. 359,

${ }^{14}$ Henneberg, W., and Stohmann, F', Über das Verhalten der Ackerkrume gegen Ammoniak und Ammoniaksalze: Annalen der Chemie, vol, 107, $p_{4} 152,1858$; Jour. Landw., vol. 3, p. 25, 1859.

${ }^{15}$ Liebig, Justus von, Über einige Eigenschafter der Ackerkrume: Annalen der Chemie, vol. 105, p. 109, 1858.

${ }^{16}$ Kullenberg, O., Über das Absorptionsvermögen des Erdbodens sind Untersuchungen : Jahrb. Fortschr. agr. Chemie, vol. 8, p. 15, 1865.
} 
quantity the higher the atomic weight of the metal with which it is combined.

Peters ${ }^{17}$ found that greater absorption occurs in alkaline solutions than in neutral solutions and that the phosphate ion is absorbed as well as the base.

Warrington ${ }^{18}$ and others attribute the removal of weak acid ions from solution by soils chiefly to interaction with ferric and aluminum oxides, with the formation of insoluble compounds.

Van Bemmelen ${ }^{19}$ showed that a soil, after extraction with hydrochloric acid, which dissolved the oxides of iron and aluminum and decomposed the silicates, would not precipitate the carbonate, phosphate, and borate radicles, though it had precipitated large amounts of them before extraction. However, if calcium carbonate is present it gives the solution an alkaline reaction, and free alkali unites with the silicic acid and is thus precipitated, while more calcium carbonate dissolves to replace the calcium hydroxide removed. Lemberg, ${ }^{20}$ who had earlier brought out the same point, adds :

Consider a carnallite bed underlain by layers of clay, and suppose the clay to be transformed in places to some product rich in potassium, as a mica. Naturally the potassium content of the metamorphic product is attributed to the overlying carnallite. The altered portions contain calcium carbonate and the others do not. Calcium carbonate and sodium chloride acting on the clay form calcium chloride and also potassium carbonate, which, being alkaline, is capable of changing the clay into potassium silicate.

Liégeois and Parmentier ${ }^{21}$ found appreciable quantities of calcium carbonate precipitated in sieved sand and sand washed with hydrochloric acid after the sand had been put in glass tubes and water containing bicarbonate percolated through it from six days to a year. They contend that the calcium bicarbonate is broken up, forming calcium carbonate, which is precipitated, and carbon dioxide, which passes off into the air.

\section{REDUCTION OF SULPHATE}

The reduction of sulphate in ground waters has been observed in the United States, Europe, and Asia. The reaction between sulphate

${ }^{17}$ Peters, E., Studien über den Boden, aus dem Laboratorium zu Tharend; Über die Absorption von Kali durch Ackererde: Landw. Vers.-Stat., vol. 2, p. 113, 1860.

${ }_{18}$ Warrington, Robert, jr., On the part taken by oxide of iron and alumina in the absorptive action of soils: Chem. Soc. London, Jour., vol. 21, p. 1, 1868.

${ }_{10}$ Van Bemmelen, J. M., Das Absorptionsvermögen der Ackererde: Landw. Vers.-Stat., vol. 23, p. $267,1879$.

${ }^{20}$ Lemberg, J., Über Silicatumwandlungen : Deutsch. geol. Gesell. Zeitschr., vol. 28, pp. 593-594, 1876.

${ }^{21}$ Liégeois, P., and Parmentier, A., Expériences sur la circulation des eaux calcareuses dans les terrains poreux: Soc. géol. Belgique Annales, vol. 45, pp. B 147-151, 1922 ; vol. 46, pp. B 235-236, 1923. 
and organic matter was suggested by Bischof ${ }^{22}$ to explain the origin of certain sulphur deposits.

In 1882 Potilitzin ${ }^{23}$ pointed out that the waters associated with oil in the Caucasian oil fields contained no sulphate.

Höfer ${ }^{24}$ noted the widespread occurrence of oil-field waters low in sulphate and suggested that the sulphate is reduced to hydrogen sulphide, which passes off while an equivalent portion of the natural gas is oxidized to carbon dioxide and carbonate. His equation follows:

or

$$
\mathrm{CaSO}_{4}+\mathrm{CH}_{4}=\mathrm{CaO}+\mathrm{H}_{2} \mathrm{~S}+\mathrm{CO}_{2}+\mathrm{H}_{2} \mathrm{O}
$$

$$
\mathrm{CaSO}_{4}+\mathrm{CH}_{4}=\mathrm{CaS}+\mathrm{CO}_{2}+2 \mathrm{H}_{2} \mathrm{O}=\mathrm{CaCO}_{3}+\mathrm{H}_{2} \mathrm{~S}+\mathrm{H}_{2} \mathrm{O}
$$

Rogers, ${ }^{25}$ Renick, ${ }^{26}$ and others have referred to occurrences of waters that appear to have been altered by these reactions.

Meyer ${ }^{27}$ and others have shown that microorganisms decompose sulphates. The sulphide-producing bacteria are anaerobic, but it is very doubtful if they can live under the conditions and at the depth of most ground waters that have undergone such alteration.

\section{IABORATORY TESTS OF REACTIONS BETWEEN WATERS AND ROCK MATERIALS FROM IMONTANA}

Some of the reactions discussed in the preceding pages were obtained in the laboratory by allowing natural waters to come into contact with samples of sandstone and shale collected by B. C. Renick in Rosebud County and by G. M. Hall in Fergus County, Mont. The rock samples were probably somewhat weathered, and one of them apparently contained salts deposited by the evaporation of ground water, but the tests illustrate the kinds of exchange and absorption that must take place underground. The results of some of the tests are given in Table 2. For convenience of comparison the analytical results are given in milligram equivalents of the radicles per kilogram of water as well as in parts per million. The quantities of water and rock given are only approximate.

22 Bischof, G., Chemische und physikalische Geologie, vol. 2, pp. 144-164, 1851.

${ }^{23}$ Potilitzin, A., Zusammensetzung des die Naphta begleitenden und aus Schlammvulkanen ausströmenden Wassers : Russ. phys.-chem. Gesell. Jour., vol. 1, p. 300, 1882 ; abstract in Deutsch. chem. Gesell. Ber., Band 15, p. 3099, 1882.

${ }^{24}$ Engler, C., and Höfer, H.; Das Wasser in den Erdölgebieten : Das Erdöl, Band 2, p. 28, 1909 .

${ }^{25}$ Rogers, G. S., Chemical relations of the oil-field waters in San Joaquin Valley, Calif. : U. S., Geol. Survey Bull. 653, 1917.

${ }^{26}$ Renick, B. C., Some geochemical relations of ground water and associated natural gas in the Lance formation of Montana : Jour. Geology, vol. 32, pp. 668-684, 1924.

${ }^{27}$ Meyer, Lothar, Chemische Untersuchung der Thermen zu Landeck in der Grafschaft Glatz: Jour. prakt. Chemie, Band 91, pp. 5-6, 1864. 
TABLE 2.-Partial analyses of water before and after treatment with rock materials

\begin{tabular}{|c|c|c|c|c|c|c|}
\hline \multirow[b]{2}{*}{ No.a } & \multicolumn{2}{|c|}{$\begin{array}{l}\text { Total hardness as } \\
\mathrm{CaCO}_{3} \text { (calculated) }\end{array}$} & \multicolumn{2}{|c|}{$\begin{array}{c}\text { Bicarbonate radicle } \\
\left(\mathrm{HCO}_{3}\right)\end{array}$} & \multicolumn{2}{|c|}{$\underset{\left(\mathrm{SO}_{4}\right)}{\text { Sulphate radicle }}$} \\
\hline & $\begin{array}{l}\text { Parts per } \\
\text { million }\end{array}$ & $\begin{array}{l}\text { Milligram } \\
\text { equiva- } \\
\text { lents per } \\
\text { kilogram }\end{array}$ & $\begin{array}{l}\text { Parts per } \\
\text { million }\end{array}$ & $\begin{array}{c}\text { Milligram } \\
\text { equiva- } \\
\text { lents per } \\
\text { kilogram }\end{array}$ & $\begin{array}{l}\text { Parts per } \\
\text { million }\end{array}$ & $\begin{array}{c}\text { Milligram } \\
\text { equiva- } \\
\text { lents per } \\
\text { kilogram }\end{array}$ \\
\hline \multirow{16}{*}{ 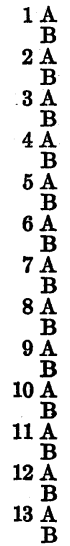 } & \multirow{16}{*}{$\begin{array}{r}497 \\
314 \\
497 \\
391 \\
497 \\
264 \\
226 \\
0 \\
257 \\
55 \\
257 \\
136 \\
293 \\
195 \\
317 \\
143 \\
107 \\
36 \\
794 \\
600 \\
107 \\
183 \\
107 \\
137 \\
107 \\
55\end{array}$} & \multirow{16}{*}{$\begin{array}{r}9.94 \\
6.28 \\
9.94 \\
7.82 \\
9.94 \\
5.38 \\
6.10 \\
5.14 \\
5.14 \\
1.10 \\
5.14 \\
2.72 \\
5.86 \\
3.90 \\
6.34 \\
2.86 \\
2.14 \\
.72 \\
15.89 \\
12.28 \\
2.14 \\
3.66 \\
2.14 \\
2.74 \\
2.14 \\
1.10\end{array}$} & \multirow{11}{*}{$\begin{array}{r}634 \\
318 \\
1,044 \\
986 \\
1,044 \\
795 \\
368 \\
305 \\
458 \\
415 \\
458 \\
331 \\
473 \\
356 \\
473 \\
379 \\
461\end{array}$} & \multirow{11}{*}{$\begin{array}{r}10.39 \\
5.21 \\
17.11 \\
16.16 \\
17.11 \\
13.03 \\
6.03 \\
5.00 \\
7.51 \\
6.80 \\
7.51 \\
5.42 \\
7.75 \\
5.83 \\
7.75 \\
6.21 \\
7.56\end{array}$} & 909 & 18.93 \\
\hline & & & & & 909 & 18.93 \\
\hline & & & & & \multirow{11}{*}{$\begin{array}{r}909 \\
1,000 \\
100 \\
450 \\
139 \\
241 \\
139 \\
173 \\
148 \\
189 \\
148 \\
165 \\
51 \\
69 \\
681 \\
938\end{array}$} & \multirow{11}{*}{$\begin{array}{r}18.93 \\
20.82 \\
2.08 \\
9.37 \\
2.89 \\
5.02 \\
2.89 \\
3.60 \\
3.08 \\
3.94 \\
3.08 \\
3.44 \\
1.06 \\
1.44 \\
14.18 \\
19.53\end{array}$} \\
\hline & & & & & & \\
\hline & & & & & & \\
\hline & & & & & & \\
\hline & & & & & & \\
\hline & & & & & & \\
\hline & & & & & & \\
\hline & & & & & & \\
\hline & & & & & & \\
\hline & & & 681 & 11. & & \\
\hline & & & & & & \\
\hline & & & & & & - \\
\hline & & & & & & \\
\hline & & & & & & \\
\hline & & & & & & \\
\hline
\end{tabular}

a A, before treatment; $\mathbf{B}$, after treatment.

1. 100 cubic centimeters of water percolated in 3 hours through 150 grams of Fort Union sandstone in a long glass tube.

2. 100 cubic centimeters of water percolated in 5 minutes through 400 grams of Fort Union sandstone in a small laboratory softener.

3. Same as test 2, except that the time of contact was 3 days.

4. 50 cubic centimeters of water in contact 2 months with 2 grams of Fort Union sandstone in a beaker.

5. 250 cubic centimeters of water in contact 16 hours with 300 grams of Fort Union sandstone in a beaker.

6. 250 cubic centimeters of water in contact 16 hours with sandstone used in test 2 .

7. 500 cubic centimeters of water in contact 22 hours with 500 grams of Eagle sandstone in a small laboratory softener.

8. 250 cubic centimeters of water in contact 18 hours with the sandstone used in test 1.

9. 25 cubic centimeters of water in contact 40 hours with 2.5 grams of Lance sandstone.

10. 250 cubic centimeters of water in contact with 400 grams of Lance sandstone in a beaker.

11. 25 cubic centimeters of water in contact 40 hours with 2.5 grams of Lance shale.

12. 25 cubic centimeters of water in contact 40 hours with 2.5 grams of Lance shale in a beaker.

13. Same as test 12, except that the time of contact was 40 days.

In test 1 the bicarbonate lost through contact with the rock was more than equivalent to the reduction in hardness; in tests $3,4,5,6$, 8 , and 10 the reduction in bicarbonate was less than the reduction in hardness. In tests 3,6 , and 8 the increase in sulphate is equivalent to less than half the decrease in bicarbonate; in tests 4,5 , and 10 it is three to seven times the decrease in bicarbonate. In test 7 the decrease in bicarbonate is almost exactly" equivalent to the decrease in hardness, but at the same time the sulphate increased by an amount equivalent to about half the loss in bicarbonate or hardness.

Tests 2 and 3, which are typical, show that a certain amount of softening may take place almost instantly and that the softening action may continue for a considerable time. This water showed comparatively little increase in sulphate. The chloride content of the waters was practically unchanged in all the tests. 
It is evident that the softening which takes place in these waters is due partly to direct adsorption of calcium and magnesium carbonates and partly to base exchange in which calcium and magnesium have been given up for sodium. Some of the reduction in bicarbonate may be due to an exchange with sulphate. However, the wide variation in amounts of sulphate taken up by the water with appárently no relation to the decrease in bicarbonate or the amount of softening makes it impossible to approximate the amount of exchange of acid radicles.

\section{CHARACTER OF WATERS FROM INDIVIDUAL FORMATIONS}

Although the waters in any geologic formation may vary widely in composition, there are nevertheless limits of concentration and general characteristics that can be given for the waters of each of the main formations in the area here considered. The analytical results represented by typical analyses and summary tables in the following discussions of the formations illustrate the changes that have been described above.

\section{WATERS FROMI THE SURFICIAL DEPOSITS}

The surficial deposits of the northern Great Plains consist of clay, sand, and gravel which have been derived from the sedimentary rocks of the area and from many kinds of rocks brought in from different areas by ice, water, or wind. These deposits range in thickness from 1 foot to over 200 feet.

The waters contained in these deposits entered the surface as meteoric waters of about the composition shown in Table 1 (p. 35). The widely varying amounts of constituents which the waters dissolved from the rock materials with which they came into contact are shown in Table 3.

TABLE 3.-Constituents of waters from surficial deposits in Montana and North Dakota

[From 142 analyses made in the water-resources laboratory of the United States Geological Survey. Parts per million]

\begin{tabular}{|c|c|c|c|}
\hline & Maximum & Minimum & A verage \\
\hline 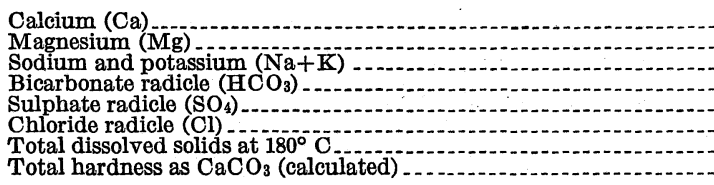 & $\begin{array}{r}500 \\
201 \\
880 \\
883 \\
1,600 \\
472 \\
3,660 \\
1,972\end{array}$ & $\begin{array}{l}15 \\
9.0 \\
4.0 \\
95 \\
12 \\
1.0 \\
223 \\
88\end{array}$ & $\begin{array}{r}124 \\
53 \\
140 \\
412 \\
382 \\
58 \\
1,027 \\
574\end{array}$ \\
\hline
\end{tabular}

The quantities of sulphate, chloride, and carbonate (calculated from bicarbonate) are plotted against the sum of the constituents for 
each of the 142 analyses of waters from the surficial deposits in the area, and the resulting curve is shown in Figure 3. A large number of the waters have less than 600 parts per million of mineral constituents in solution. Examination of the individual analyses shows that waters from these deposits may be divided into two types-those with calcium, magnesium, and carbonate predominating, of which $\mathrm{A}$, Figure 4, is representative; and those with calcium, magnesium, and sulphate predominating, of which B, Figure 4, is representative. The increase in solids above 600 parts per million is generally due to the addition of sodium and sulphate, as represented by C, Figure 4. Figure 3 shows that after the concentration has reached about 700 parts per million sulphate increases in definite proportion to the total

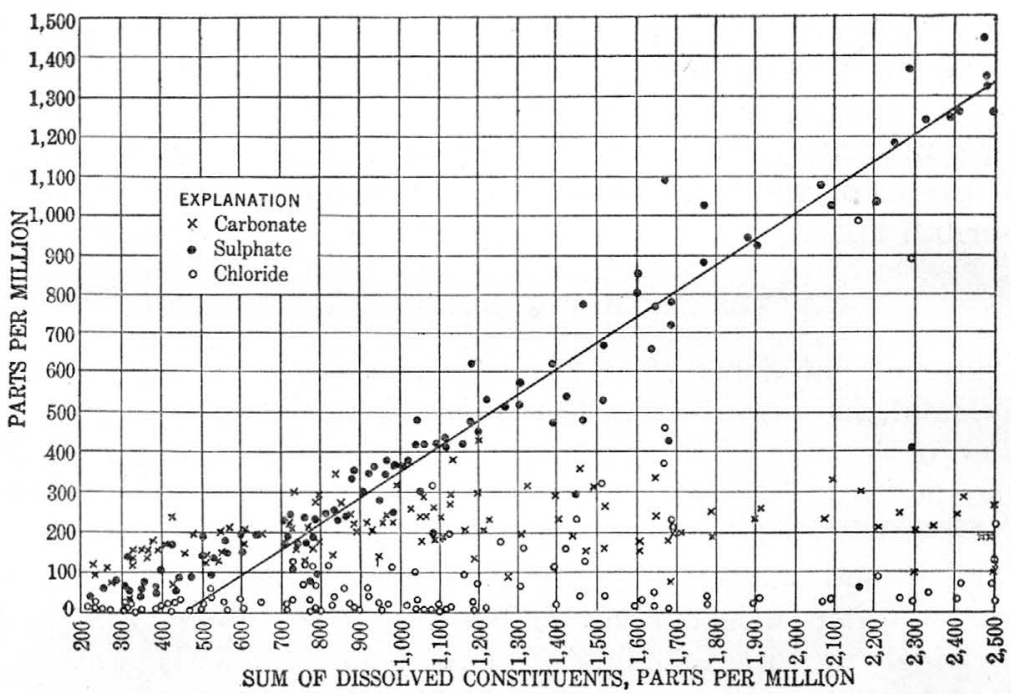

Figures 3.-Relation of carbonate, sulphate, and chloride to sum of dissolved constituents in waters from surficial deposits of northern Great Plains

dissolved solids but that bicarbonate and chloride have little relation to concentration. Individual analyses show that sodium is generally the added basic radicle when the concentration is high.

Table 3 shows that practically all the waters are hard. As previously explained this hardness is due to the solution of calcium and magnesium liberated by disintegration of the feldspars and other rock materials. The analyses of waters from the surficial deposits all show bicarbonate with no carbonate, because carbonates are changed to bicarbonates in the presence of air and carbon dioxide.

Many highly mineralized waters occur in surface deposits as a result of concentration by evaporation, which takes place in the waters of such deposits after they have accumulated from higher places either as run-off or as seepage water. After a dashing rain 
or rapidly melting snow the water drains off the higher slopes, carrying with it any soluble materials picked up from the surface, and accumulates in the lower places or valleys, which serve as a reservoir. Water that seeps into the ground may be carried to the lower places in the water table, where in dry spells it is brought to the surface again by capillary action. This water carries a variable amount of dissolved material, which is deposited upon evaporation. Any water in the low places that continues to seep into the ground contains great quantities of dissolved minerals, and if a well is driven where such water can enter it a highly mineralized water will be obtained.

\section{WATERS FROM THF FORT UNION AND LANCE FORIMATIONS}

The Fort Union and Lance formations are sedimentary deposits that were laid down in fresh water, except the Cannonball marine member of the Lance formation. The Fort Union consists of sandstone and soft shale, with persistent beds of lignite. It is underlain by the Lance formation, which is very similar in composition. The Fort Union is overlain in parts of the region by late Tertiary deposits, glacial

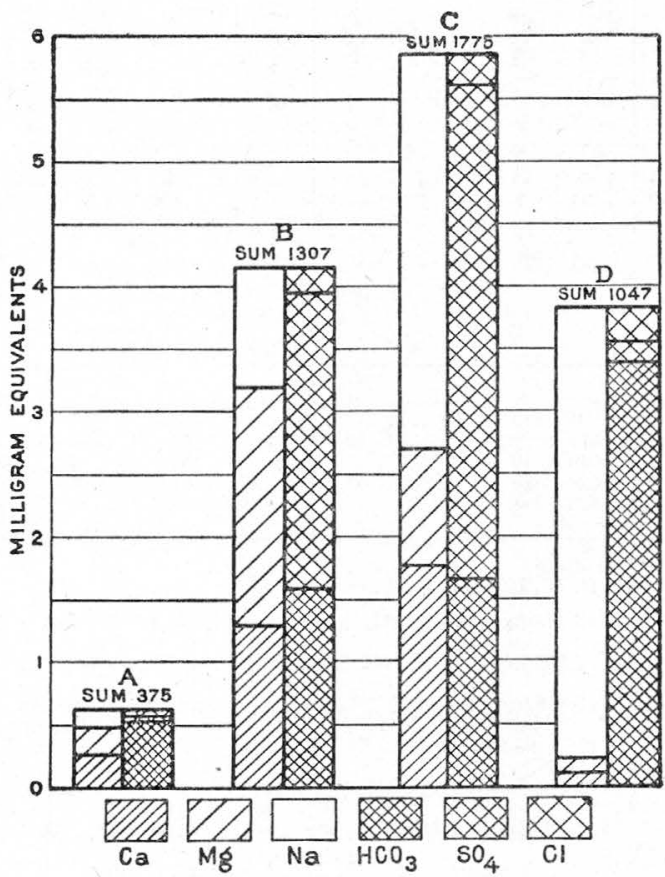

Figure 4.-Dissolved constituents in typical waters from northern Great Plains. (For explanation of diagram, see Collins, W. D., Graphic representation of water analyses: Ind. and Eng. Chemistry, vol. 15 , No. 4 , p. 394,1923 ) drift, or other surficial deposits. Where it is eroded away the Lance is exposed. The maximum thickness of the two is about 2,000 feet. The waters in these formations are very similar and will be considered together.

Waters of meteoric origin reaching these formations have first percolated through the surficial deposits and dissolved a variable amount of mineral matter. Analyses show that the waters from surficial deposits overlying the Fort Union and Lance formations generally contain from 300 to 1,000 parts per million of total dissolved solids, of which calcium and magnesium are the principal 
basic radicles and make the waters hard. The changes in chemical character of the waters that have percolated into the Fort Union and Lance formations are shown by the analyses discussed below.

TABLE 4.-Typical analyses of waters from Fort Union and Lance formations [Parts per million]

Fort Union

\begin{tabular}{|c|c|c|c|c|c|c|c|c|c|c|c|c|c|}
\hline 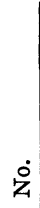 & 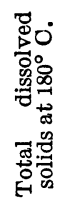 & 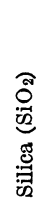 & $\begin{array}{l}\underset{\text { D }}{\text { 总 }} \\
\text { 总 }\end{array}$ & 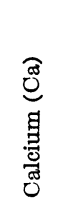 & 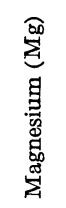 & 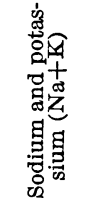 & 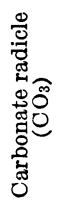 & 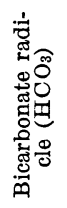 & 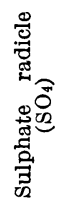 & 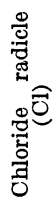 & 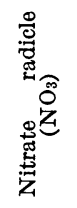 & 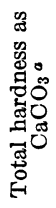 & 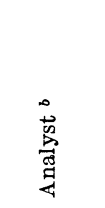 \\
\hline $\begin{array}{l}1 \\
2\end{array}$ & $\begin{array}{l}2,345 \\
1,294\end{array}$ & $\begin{array}{l}15 \\
8.6\end{array}$ & $\begin{array}{r}0.75 \\
.33\end{array}$ & $\begin{array}{l}16 \\
4.0\end{array}$ & $\begin{array}{l}4.8 \\
2.9\end{array}$ & $\begin{array}{l}882 \\
456\end{array}$ & $\begin{array}{l}29 \\
38\end{array}$ & $\begin{array}{r}2,152 \\
522\end{array}$ & $\begin{array}{r}31 \\
506\end{array}$ & $\begin{array}{l}110 \\
8.0\end{array}$ & $\begin{array}{l}\text { Trace. } \\
\text { Trace. }\end{array}$ & $\begin{array}{l}60 \\
22\end{array}$ & $\begin{array}{l}\text { H. B. R. R. } \\
\text { H. B. R. }\end{array}$ \\
\hline 3 & 1,010 & 13 & .40 & 5.2 & 1.8 & $\mathrm{Ta}$ & 0 & 964 & 7.2 & 78 & Trace. & 20 & H. B. R. \\
\hline 4 & 1,351 & 28 & 5.3 & 144 & 135 & & 0 & 517 & 634 & 11 & 1.5 & 914 & H. B. R. \\
\hline
\end{tabular}

Lance

\begin{tabular}{r|c|c|c|c|c|c|c|c|c|c|c|c|c|c}
\hline 5 & 1,580 & 21 & 0.31 & 4.8 & 3.4 & 640 & 0 & 1,332 & 6.6 & 236 & Trace. & 26 & H. B. R. \\
6 & 1,204 & 12 & Trace. & 5.2 & 2.3 & 488 & 43 & 932 & 3.3 & 166 & 1.5 & 22 & H. B. R. \\
7 & 477 & 8.8 & .40 & 12 & 6.1 & 155 & 0 & 381 & 66 & 3.0 & Trace. & 55 & H. B. R. \\
8 & 640 & 10 & .20 & 61 & 29 & 134 & 0 & 444 & 165 & 12 & 10 & 271 & H. B. R. \\
9 & 1,328 & 10 & .13 & 6.2 & .8 & 467 & 36 & 473 & 518 & 32 & 1.6 & 19 & C. S. H. \\
10 & 208 & 4.0 & .12 & 30 & 17 & $a 8.5$ & 0 & 156 & 31 & 2.0 & .38 & 145 & C. S. H. \\
\hline
\end{tabular}

a Calculated.

b H. B. R., H. B. Riffenburg, U. S. Geol. Survey; C. S. H., C. S. Howard, U. S. Geol. Survey.

1. Well 175 feet deep in SE. 1/4 sec. 21, T. 155 N., R. 85 W., Ward County, N. Dak. Collected July 5, 1921.

2. Well 300 feet deep in NE. 1/4 sec. 27, T. 140 N., R. 102 W., Billings County, N. Dak. Collected July $20,1921$.

3. Well 178 feet deep in NE. $1 / 4$ sec. 3, T. 3 S., R. 44 E., Rosebud County, Mont. Collected July 24, 1923. 4. Well 48 feet deep in NW.1/4 sec. 6, T. 1 N., R. 40 E., Rosebud County, Mont. Collected July 30, 1923. 5. Well 2,100 feet deep in SW. 1/4 sec. 29, T. 154 N., R. 100 W., Williams County, N. Dak. Collected June 22, 1921

6. Well 365 feet deep in SW. $1 / 4$ sec. 22, T. 1 N., R. 44 E., Rosebud County, Mont. Collected July 23, 1923.

7. Well 19 feet deep in SE. $1 / 4$ sec. 23, T. 6 N., R. 39 E., Rosebud County, Mont. Collected August 20, 1923.

8. Well 53 feet deep in NE. $1 / 4$ NE. 1/4 sec. 23, T. 10 N., R. 34 E., Rosebud County, Mont. Collected October 8, 1923 .

9. Well 100 feet deep in SE. 1/4 sec. 7, T. 3 N., R. 26 E., Yellowstone County, Mont. Collected October $27,1921$.

10. Spring in S. 1/2 sec. 9, T. 5 N., R. 36 E., Treasure County, Mont. Collected September 29, 1921.

Analyses of characteristic waters from the Fort Union and Lance formations are given in Table 4; maximum, minimum, and average amounts of constituents of 118 analyses of waters from these formations are shown in Table 5; the relation of quantities of certain constituents to the total is shown in Figure 5; and the relation of total hardness to depth of wells in the Fort Union and Lance formations is shown in Figure 6 . The waters represented by analyses 4, 7, 8, and 10 in Table 4 came from shallow wells and with the exception of No. 7 are similar in character to those represented by A and B, Figure 4, which is typical of the shallow-well waters of these formations as well as the waters of the surficial deposits. Tables 4 and 5 and the individual analyses show that nearly all the 
waters from shallow wells in the Fort Union and Lance formations are hard and are similar in character to the waters from the surficial deposits.

\section{TABLE 5.-Constituents of waters from Fort Union and Lance formations}

[Based on 118 analyses made in water-resources laboratory of United States Geological Survey. Parts per million]

Calcium (Ca)

Magnesium ( $\mathrm{Mg}$ )

Sodium and potassium $(\mathrm{Na}+\overline{\mathrm{K}})$

Bicarbonate radicle $\left(\mathrm{HCO}_{3}\right)$

Sulphate radicle $\left(\mathrm{SO}_{4}\right)$

Chloride radicle $(\mathrm{Cl})$

Total dissolved solids at $180^{\circ} \mathrm{C}$

Total hardness as $\mathrm{CaCO}_{3}$ (calculated)

\begin{tabular}{|r|r|r|r|r|r}
\multicolumn{3}{|c|}{ Fort Union } & \multicolumn{3}{c}{ Lance } \\
\cline { 1 - 4 } $\begin{array}{c}\text { Maxi- } \\
\text { mum }\end{array}$ & $\begin{array}{c}\text { Mini- } \\
\text { mum }\end{array}$ & $\begin{array}{c}\text { Aver- } \\
\text { age }\end{array}$ & $\begin{array}{c}\text { Maxi- } \\
\text { mum }\end{array}$ & $\begin{array}{c}\text { Mini- } \\
\text { mum }\end{array}$ & $\begin{array}{c}\text { Aver- } \\
\text { age }\end{array}$ \\
\hline & & & & & \\
336 & 4.0 & 54 & 110 & 3.8 & 21 \\
215 & 1.0 & 41 & 71 & .8 & 13 \\
920 & 8.0 & 286 & 957 & 8.0 & 470 \\
2,152 & 63 & 666 & 1,674 & 155 & 789 \\
2,440 & 2.6 & 316 & 1,594 & 1.0 & 379 \\
306 & 1.0 & 33 & 533 & 2.0 & 72 \\
3,735 & 274 & 1,080 & 2,911 & 170 & 1,381 \\
1,722 & 15 & 295 & 516 & 14 & 108 \\
\hline
\end{tabular}

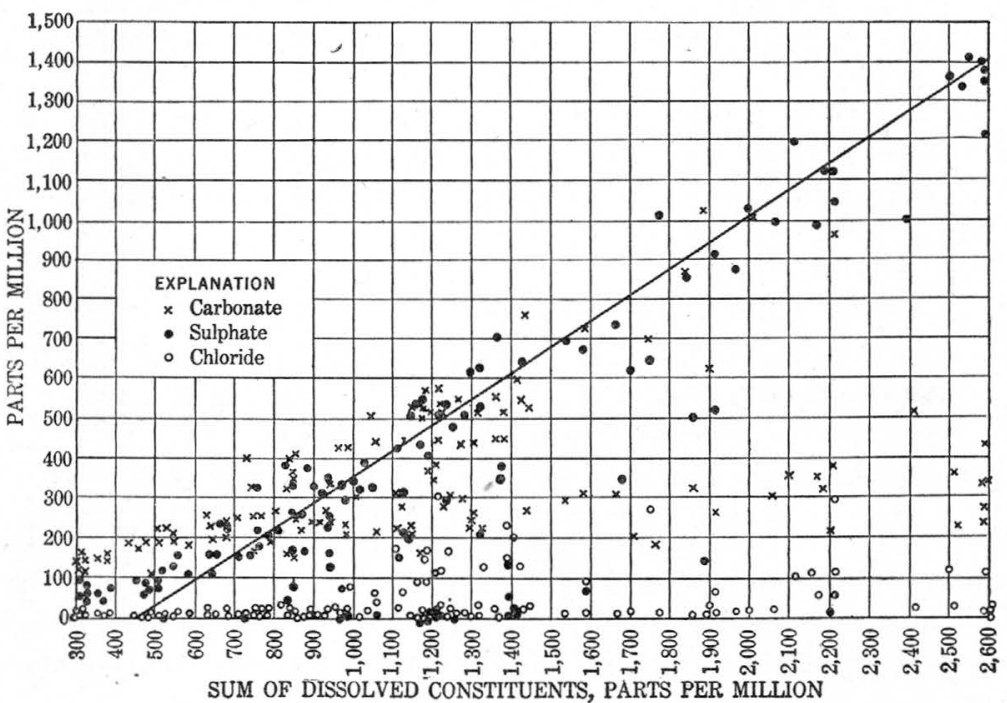

Figure 5.-Relation of carbonate, sulphate, and chloride to sum of dissolved constituents in waters from Fort Union and Lance formations

Analyses 1, 2, 3, 5, 6, and 9, Table 4, represent deep-well waters, of which D, Figure 4, is typical, and show an entirely different character from that of the shallow-well waters in the Fort Union and Lance formations. The striking features of the deep-well waters are that they are all soft, that many of them contain carbonate as well as bicarbonate, and that although some of them contain large amounts of sulphate (analyses 2 and 9 ), others contain very little (analyses $1,3,5$, and 6 ).

$50065^{\circ}-25-4$ 
Figure 6 shows that a definite relation exists between hardness and depth of wells. The waters from wells 100 to 125 feet deep are generally soft, and all the waters below this depth are soft. A comparison of the analyses of the deep-well waters with those of waters from the shallow wells shows that a definite softening action has taken place in the deep waters. Renick ${ }^{28}$ concludes from a microscopic examination of some of the rock materials from Rosebud County, Mont., that the softening action in these formations is due to leverrierite.

The analyses and the experiments discussed on page 39 suggest that some of the softening may be due to adsorption of calcium and magnesium carbonate. Analyses 1, 2, 6, and 9, like many other analyses of waters of these formations, show carbonate in variable

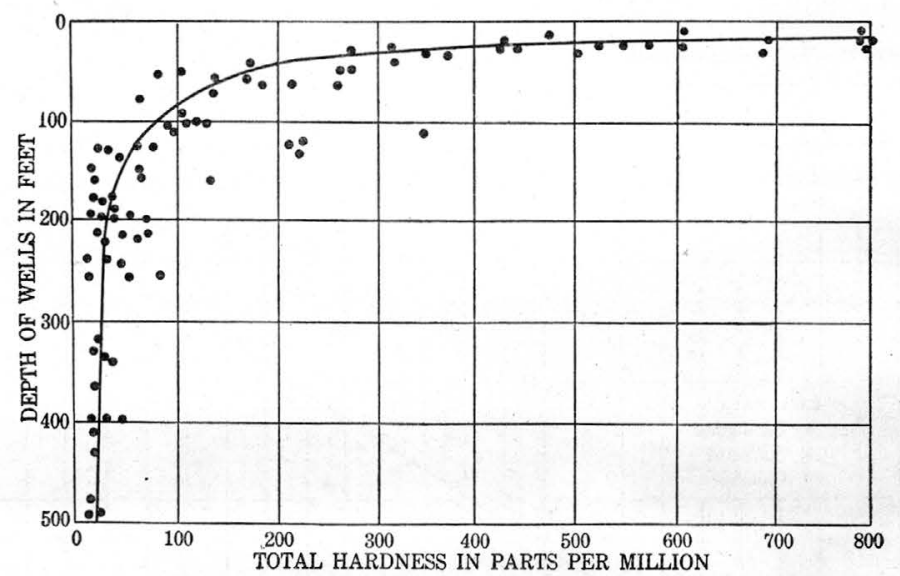

FIGURE 6.-Relation of total hardness to depth of wells in Fort Union and Lance formations

amounts, together with bicarbonate. Large quantities of calcium and magnesium can not remain in solution in the presence of carbonate, and these constituents may have been precipitated as the waters seeped through the rocks that contained carbonaceous materials.

From a comparison of Figures 3 and 5 it will be seen that in most waters in the surficial deposits carbonate equivalent to the bicarbonate is well under 300 parts per million, whereas in many waters from the Fort Union and Lance formations nearly twice as much is found, and a few contain bicarbonate equivalent to over 1,000 parts of carbonate. Figures 3 and 5 show that there is no noticeable difference in the amounts of chloride in waters from the two horizons. Individual analyses of waters from wells more than 100 feet deep in the Fort Union and Lance formations do not show

${ }^{28}$ Renick, B. C., Base exchange in ground water by silicates as illustrated in Montana : U. S. Geol. Survey Water-Supply Paper 520, pp. 53-72, 1924. 
much variation in the amount of dissolved constituents as the depth of wells increase.

Figures 3 and 5 show sulphate to be the added basic radicle in the highly concentrated waters of the surficial deposits and of the Fort Union and Lance formations. Figure 5 shows that in many of the waters from the Fort Union and Lance formations the quantity of sulphate is very low and the bicarbonate high, a relation which is not shown in Figure 3 for waters of the surficial deposits. Examination of analyses of waters from the surficial deposits and from the Fort Union and Lance formations shows that the deepwell waters in the Fort Union and Lance formations are the only ones that contain small amounts of sulphate. Analyses 1, 3, 5, and 6 in Table 4, like many other analyses of waters from these formations, show that the waters deficient in sulphate contain unusually large amounts of bicarbonate. The relation of sulphate to bicarbonate in these waters and in the waters of shallow wells in these formations or in the surficial deposits may be explained as due either directly or indirectly to the action of the lignite, carbonaceous shale, or natural gas contained in the rocks of the Fort Union and Lance formations in the manner discussed by Höfer, referred to on page 39. It appears from examination of the analyses that the waters containing sulphate, such as those represented by A and B, Figure 4, have had their sulphate reduced on sinking to greater depths and at the same time have taken up large amounts of bicarbonate. (See analyses $1,3,5$, and 6.) The waters showing such changes came from wells that draw on strata near lignite beds or beds containing considerable natural gas. According to the reaction described by Höfer an equivalent amount of bicarbonate is produced for the sulphate reduced. Many waters of the area appear to show this relation, but others may have been further altered later, so that the effect of this change is concealed.

Below is a comparison of the acid radicles shown by analyses of two waters from different depths in the same section in Rosebud County, Mont., that are typical of many waters throughout the area.

TABLE 6.-Constituents of waters from shallow and deep wells in the same locality, Rosebud County, Mont.

[Miligram equivalents per kilogram]

\begin{tabular}{|c|c|c|}
\hline , & $\begin{array}{l}\text { Shallow } \\
\text { well }\end{array}$ & $\underset{\text { weell }}{\text { Deep }}$ \\
\hline $\begin{array}{l}\text { Carbonate radicle }\left(\mathrm{CO}_{3}\right) \\
\text { Bicarbonate radicle }\left(\mathrm{HCO}_{3}\right) \\
\text { Sulphate radicle }\left(\mathrm{SO}_{4}\right) \\
\text { Chloride radicle (Cl) }\end{array}$ & $\begin{array}{l}0.00 \\
8.47 \\
4.41 \\
.20\end{array}$ & $\begin{array}{r}1.20 \\
12.00 \\
.06 \\
.51\end{array}$ \\
\hline : & 13.08 & 13. 77 \\
\hline
\end{tabular}




\section{WATERS FROM THE MONTANA GROUP}

The Montana group occurs throughout most of the area considered. Its divisions vary with the locality, as shown in the geologic column (p. 33). The group is essentially a salt-water deposit. $^{20}$ The rocks consist of shale, except where they are interstratified with sandstone and sandy shale. Many of the sandstone beds are lenticular and not very thick. The group is not waterbearing throughout, though some of the larger sandstone beds, as the Judith River, the Fox Hills, and the Eagle, yield considerable water. The shales do not give up their water readily, and few wells sunk in them yield satisfactory supplies.

Table 7 gives the maximum, minimum, and average amount of constituents contained in the waters from this group.

\section{TABLE 7.-Constituents of waters from the Montana group}

[Based on 83 analyses made in the water-resources laboratory of the United States Geological Survey. Parts per million]

\begin{tabular}{|c|c|c|c|}
\hline & Maximum & Minimum & Average \\
\hline 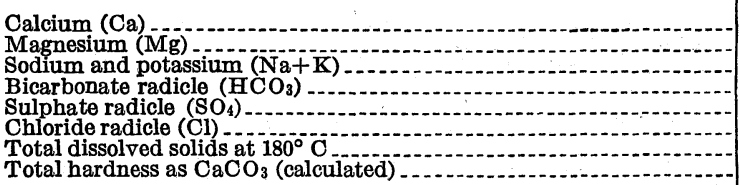 & $\begin{array}{r}523 \\
285 \\
2,438 \\
1,691 \\
5,609 \\
1,048 \\
8,726 \\
1,907\end{array}$ & $\begin{array}{r}3.0 \\
1.7 \\
16 \\
44 . \\
5.9 \\
1.0 \\
336 \\
18\end{array}$ & $\begin{array}{r}82 \\
54 \\
457 \\
562 \\
676 \\
80 \\
1,742 \\
460\end{array}$ \\
\hline
\end{tabular}

Nearly all the waters analyzed came from shallow dug wells, many of which are in the soils and weathered portions of the rocks. These waters are similar in character to those of the surficial deposits. Probably the greatest variation is in concentration. Many of the waters resemble those represented by A, B, and C, Figure 4, and others resemble waters from the Lance and Fort Union formations. Bowen ${ }^{30}$ reports that some of the sandstones of this group resemble those of the Lance formation in character and composition, from which it may be inferred that the water in these beds has been subjected to a softening action similar to that which has occurred in the Fort Union and Lance formations. However, only a very few waters with hardness less than 50 parts per million have been found in these beds. Perhaps if the sandstones were thicker and the wells deeper more soft waters would be found.

The chlorides are higher in many waters from the east end of the area than in those from the west end. Many of the high-chloride

\footnotetext{
${ }^{29}$ Stanton, T. W., and Hatcher, J. B., Geology and paleontology of the Judith River beds : U. S. Geol. Survey Bull. 257, 1905.

${ }^{30}$ Bowen, C. F., Gradations from continental to marine conditions of deposition in central Montana during the Eagle and Judith River epochs : U. S. Geol. Survey Prof. Paper 125 , p. 11, 1920 .
} 
waters come from lenticular deposits of sandstone and have neither migrated far nor been replaced by meteoric waters, because the relatively impervious shale in which the sandstone lenses occur has held the waters of deposition within the sandstone. The sandstones in the west end of the area are partly fresh-water deposits, and they were laid down in larger areas and thus afford more favorable conditions for washing by the meteoric waters under static pressure toward the west.

Table 7 and the individual analyses show that some of these waters are higher in bicarbonate than those from the surfieial deposits and that some of them contain very small amounts of sulphate. This condition is probably due to the formation of carbonates with the reduction of sulphate in the same manner as in waters in the Fort Union and Lance formations, described above.

Many of the waters from the Montana group appear not to have undergone extensive alteration but simply to have dissolved the soluble materials of the rocks. Others appear to have undergone alterations similar to those in the waters of the Fort Union and Lance formations. (See pp. 43-47.)

Waters containing much more than 1,000 parts per million of mineral matter generally have sodium and sulphate as the added constituents, but in a few calcium, magnesium, and sulphate are the constituents in excess of the quantities found in the less mineralized waters.

TABLE 8.-Typical analyses of waters from the Dakota and Lower Cretaceous sandstones

[Parts per million]

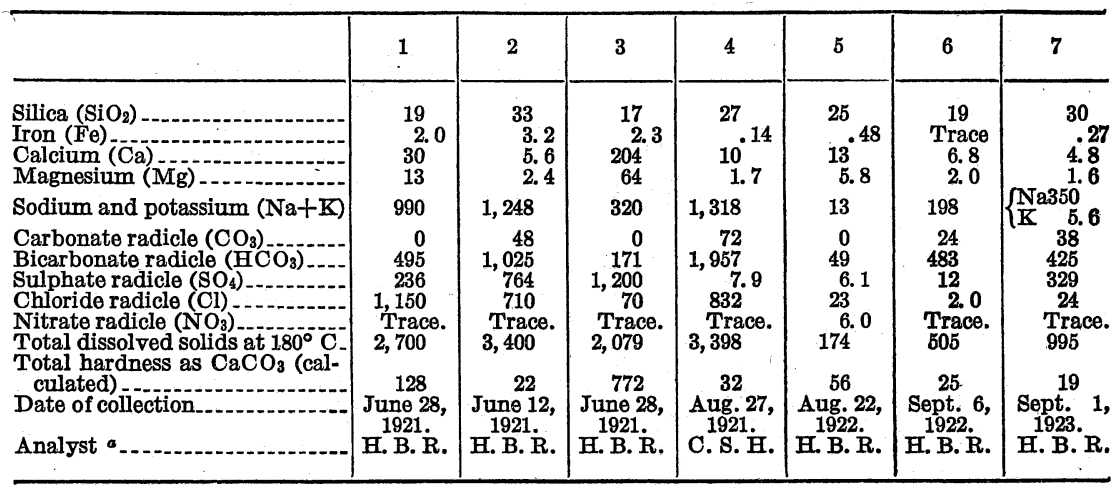

a H. B. R., H. B. Riffenburg, U. S. Geol. Survey; C. S. H., C. S. Howard, U. S. Geol. Survey.

1. Well 1,087 feet deep, SW. $1 / 4$ sec. 12, T. 129 N., R. 63 W., Dickey County, N. Dak.

2. Well 2,235 feet deep, SW. $1 / 4$ sec. 31 , T. 150 N., R. 72 W., Wells County, N. Dak.

3. Well 1,385 feet deep, SW. 1/4 sec. 12, T. 129 N., R. 63 W., Dickey County, N. Dak.

4. Well 2,235 feet deep, SE. $1 / 4$ sec. 7, T. 2 S., R. 24 E., Yellowstone County, Mont.

5. Well 60 feet deep, NW. i/4 sec. 7, T. 13 N., R. 24 E., Fergus County, Mont.

6. Well 417 feet deep, NE. $1 / 4$ sec. 5, T. 15 N., R. 18 E., Fergus County, Mont.

7. Well 1,860 feet deep, SE. $1 / 4$ sec. 1 , T. 15 N., R. 28 E., Fergus County, Mont. 


\section{WATERS FROII THE COLORADO GROUP}

The Colorado shales are of very fine grain and are poor. water bearers. They are similar to the shales of the Montana group and in places yield small amounts of water similar in character to the water in the Montana group. Not enough samples from this group were analyzed to warrant a detailed study. In the area here discussed it is drawn upon for a water supply only to a minor extent in a small area in Montana, where it forms the bedrock. The waters are generally hard and highly mineralized and are unsatisfactory for domestic use.

\section{WATERS FROII THE DAKOTA AND LOWER CRETACEOUS SANDSTONES}

The Dakota sandstone consists of sandstone interstratified with shaly beds. It occurs throughout the area and is overlain by the Colorado group except in the Red River valley of North Dakota, where surficial deposits form the overlying beds, and in small areas in Montana, where the overlying beds have been eroded away. It has not been reached by drilling in the central part of the area, but farther east it is valued for the great quantity of water it yields by artesian flow. Of the Dakota waters analyzed many of those from the western part of the area came from deep wells being drilled for oil. Those from the eastern part came from the first, second, or third sand in the Dakota sandstone.

Table 8 gives representative analyses of waters from the Dakota sandstone, and Table 9 gives the maximum, minimum, and average quantities of dissolved constituents in the 57 waters analyzed.

TABLE 9.-Constituents of waters from the Dakota and Lower Cretaceous sandstones

[Based on 57 analyses made in the water-resources laboratory of the United States Geological Survey. Parts per million]

\begin{tabular}{|c|c|c|c|}
\hline & Maximum & Minimum & A verage \\
\hline 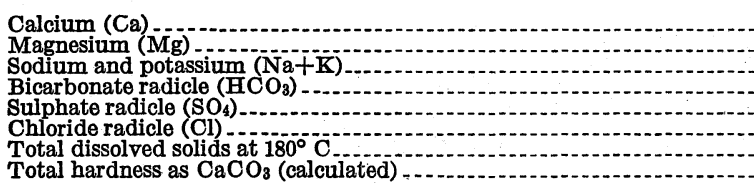 & $\begin{array}{r}204 \\
72 \\
1,710 \\
1,402 \\
1,989 \\
1,832 \\
4,799 \\
772\end{array}$ & $\begin{array}{r}5.0 \\
1.2 \\
3.0 \\
49 \\
2.0 \\
2.0 \\
174 \\
17\end{array}$ & $\begin{array}{r}60 \\
16 \\
629 \\
662 \\
542 \\
355 \\
1,988 \\
150\end{array}$ \\
\hline
\end{tabular}

The waters from different localities and horizons differs considerably in character. Shepard ${ }^{31}$ found that the artesian waters from

${ }^{31}$ Shepard, J. H., The artesian waters of South Dakota: South Dakota Agr. College and Exper. Sta. Bull. 41, 1895. 
the first sand are generally soft and high in chloride, but that waters from the lower sands are hard and generally contain relatively small amounts of chloride. Meinzer ${ }^{32}$ noted similar conditions in the Cretaceous waters in southwestern Minnesota. Analyses 1 and 2, Table 8, represent waters from the first sand and analysis 3 a water from the second sand. These waters are representative of waters from North Dakota and of those from South Dakota cited by Shepard. They confirm the characteristics brought out by Shepard. Analyses 5, 6, and 7 are typical of the waters from the west end of the area, where no difference was noted in the character of waters from different horizons. These analyses show that the waters are soft, that some of them contain very small quantities of sulphate, that all are low in chloride content, and that none are highly mineralized. The waters of the west end are not so highly mineralized as those of the east end: they are, if anything, lower in chloride than waters from the second sand, and they are comparatively soft, like those from the first sand. Sulphate is high in all the waters from the second sand and in most of those from the first sand. No reduction of sulphate is apparent in these waters, but analyses of some of the waters in the west end of the area indicate that sulphate has been reduced, as in the waters of the Fort Union and Lance formations. Table 8 shows that waters from both ends of the area contain carbonate as well as bicarbonate. Analysis 3 shows a relatively small content of bicarbonate, which was noted in several of the waters from the east end. It has been suggested that the hardness of the waters from the second sand is due to the large amount of limestone lying at the base of the sandstone.

The water represented by analysis 4 is the only one in the whole western part of the area that shows either so high a concentration or so much chloride.

It appears that the waters in the first sand in the east end of the area have undergone only one characteristic alteration-namely, softening-though the sulphate in some of them may have been reduced. Although the analyses do not show a similarity to sea water, they indicate that connate waters still occur in the rocks and that such waters may have been greatly diluted with meteoric water. Analyses of waters from the western part of the area and from the deeper sands in the eastern part suggest that these waters are entirely of meteoric origin and have dissolved their load of mineral matter from the materials with which they have come into contact, unless the deposits were laid down in a fresh-water lake.

sall, C. W., Meinzer, O. E., and Fuller, M. L., Geology and underground waters of southern Minnesota : U. S. Geol. Survey Water-Supply Paper 256, pp. 54-78, 132, 210, 304, 1911. 


\section{SUMMARY}

The relátive proportions of the several constituents in the waters of the northern Great Plains, whether from the fresh-water deposits or from the rocks that were laid down in a salty sea, indicate that the ground waters are in general of meteoric origin and have replaced the waters of sedimentation, and this conclusion is supported by the fact that they contain only small quantities of chloride. The deepseated waters in the east end of the area may be mixtures of connate and meteoric waters. Extensive migration and the partial expulsion of the included waters have been due to the consolidating processes that took place as deposition continued. The later tilting of the beds in the Rocky Mountains has caused more or less movement in the waters toward the east by hydrostatic pressure, and the exposure of the formations in the foothills affords an opening to the rocks to receive a continuous supply of rain and snow water. Cementation, heat, and the chemical and mineral changes within the rocks also assisted in the migration and expulsion of the interstitial waters.

Meteoric waters containing a small amount of mineral matter absorbed from the air have dissolved more material from the soil and rocks through which they percolated. The chemical character of these waters has been altered by reaction with the materials with which they have come into contact. The changes in the waters from the time they entered the soil as rain to the time that they were analyzed have resulted from the solution of such compounds as sulphates and carbonates of calcium, magnesium, and sodium; from the redeposition and exchange of part of the constituents; and from chemical reactions brought about by the oxidation of pyrite or by the reduction of sulphates, whether by bacteria or organic matter.

Some of the shallow waters have been concentrated by evaporation, but there is little evidence of such concentration of the deep-seated waters. 